\title{
The effect of foliar application of Ulva rigida extract on the growth and biochemical parameters of wheat plants
}

\author{
Salma Latique ${ }^{1, *}$, Reda Ben Mrid ${ }^{2,3}$, Imad Kabach ${ }^{2}$, Abdelaziz Yasri ${ }^{3}$, Anass Kchikich ${ }^{2}$, Mohamed Nhiri ${ }^{2}$, Mimoun El \\ Kaoua $^{4}$, Allal Douira ${ }^{1}$, and Karima Selmaoui ${ }^{1}$ \\ ${ }^{1}$ Department of Biology, Plant, animal and agro-industry Production laboratory, Faculty of Sciences, Ibn Tofail University, Kenitra, \\ BP.133, 14020, Morocco. \\ ${ }^{2}$ Laboratory of Biochemistry and Molecular Genetics, Faculty of Sciences and Techniques of Tangier, BP 416, 90000, Morocco. \\ ${ }^{3}$ AgroBioSciences Research Division, Mohammed VI Polytechnic University, Benguerir 43150, Morocco. \\ ${ }^{4}$ Department of Biology, Laboratory of Biotechnology and molecular bioengineering, Faculty of Sciences and Technology FSTG, \\ Cadi Ayyad University, Gueliz-Marrakech 40000, Morocco.
}

\begin{abstract}
Many research studies have shown the importance of seaweed extract in agriculture. Marine macroalgae are rich in diverse compounds like lipids, proteins, carbohydrates, phytohormones, amino acids, osmoprotectants and minerals. In this study, we have tried to characterize Moroccan macroalgae species Ulva rigida collected from the coastal area of Akhfenir in order to evaluate their potential to improve growth plant. The proximate composition, mineral element (Ca, $\mathrm{K}, \mathrm{Mg}, \mathrm{Na}$ and $\mathrm{Cl}$ ), pigments, amino acid, proteins, lipids, polyphenol contents were determined in liquid extract obtained from green seaweed (SWE) Ulva rigida. Results show that the application of SWE at different concentrations $(0,12.5,25,50 \%)$ significantly enhanced growth parameters, especially with $25 \%$ of seaweed liquid extract. Therefore, algal treatment by foliar application is proved to be an effective technique to improve the growth of wheat plants. This study provides important information on the characterization, identification and utilization of seaweed resources for agriculture as biostimulants.
\end{abstract}

\section{Introduction}

Organization (FAO) projected a $60 \%$ increase in food demand by 2050 than that of 2005/2007 supported on recent food-demand projections especially [1]. While, global climate change already has negative effects on crop yields, and such impacts are likely to become even stronger later during this century [2]. For that, the use of marine algae is promising and provides suitable solutions to beat pollution problems caused by the extensive use of chemical fertilizers and industrialization [3].

In recent years, seaweed liquid extract has newly gained importance as a foliar spray for several crops, including cereals, vegetables and spices [4]. Furthermore, many studies concerning plant growth stimulating effects of marine algae are carried out [5].

Seaweed extracts are known to contain a large range of bioactive compounds like antioxidants, plant growth hormones, osmoprotectants, mineral nutrients [6].

However, as is mentioned by many authors, plant growth promotion by seaweed extracts is usually observed [7,8], but the mechanisms of stimulation of plant growth aren't entirely known in many cases [6].

Globally, wheat is within the second rank among the cultivated worldwide cereals crops after maize and rice and under different climate ranges [9].
Considering the commercial importance of this plant, the physiological and biochemical effects of foliar seaweed application were analysed and therefore the results obtained on this aspect are presented in this paper. The main objective of the present study is to determine the proximate composition of the green algae Ulva rigida collected from the coastal area of Akhfenir and to evaluate their potential as natural fertilizer in wheat plants.

\section{Material and methods}

\subsection{Algae material}

In this research, green seaweed (Ulva rigida) was used. Ulva species (Ulvophyceae), are widely distributed across the globe, being one of the most heavily traded edible seaweeds [10]. Ulva rigida, also known as sea lettuce, is a cosmopolitan species [11]. This algae's tallus size varied from $1-2 \mathrm{~cm}$ up to $30 \mathrm{~cm}$ and clings to the substrate with a short stem [12].

\subsection{Seaweed liquid preparation}

The seaweed extracts were prepared from one macroalgae species Ulva rigida (Chlorophyceae)

* Corresponding author: $\underline{\text { salma.latique@uit.ac.ma }}$ 
collected from the coastal area of Akhfenir near to the Laâyoune city (Morocco) in October 2019. The algae were hand-picked and thoroughly washed with seawater to remove all the unwanted impurities, adhering sand particles, and epiphytes. Morphologically, distinct thalli were placed separately in new polythene bags and kept in an ice box containing slush ice and transported to the laboratory. Samples were washed thoroughly under ambient temperature using tap water to remove the surface salt and then blotted to remove excess water. Fresh material was cut into small pieces and preserved at $-20{ }^{\circ} \mathrm{C}$ until use.

$1 \mathrm{~kg}$ of the fresh crushed algal material was mixed with 1 liter of distilled water and boiling separately for one hour, then the mixture was filtered to remove debris [13]. This filtrate represented the $100 \%$ crude extract. The $25 \%, 50 \%$ and $75 \%$ concentrations were subsequently prepared.

\subsection{Estimation of Mineral}

The powdered algae samples were ignited and incinerated in a muffle furnace (Karl Kolb Scientific, Technical Supplies, D-6072) at $550{ }^{\circ} \mathrm{C}$ for $4 \mathrm{~h}$. The mineral constituents $(\mathrm{Ca}, \mathrm{K}, \mathrm{Na}, \mathrm{Mg}$ and $\mathrm{Cl}$ ) were dissolved in $\mathrm{HNO}_{3}$ [14] and the mineral were determined using an atomic absorption spectrophotometer (Analytik Jena AAS Zeenit 700).

\subsection{Estimation of Chlorophyll}

The amount of chlorophyll present in the leaves was estimated by the method of [15]. $500 \mathrm{mg}$ of leaf tissue was kept in a pestle and mortar with $10 \mathrm{ml}$ of $80 \%$ acetone and it was ground well and the homogenate was centrifuged at $3000 \mathrm{rpm}$ for 15 minutes and the supernatant was stored. The pellet was extracted by repeated washing with $5 \mathrm{ml}$ of $80 \%$ acetone till it became colorless. All the extracts were pooled and utilized for chlorophyll determination. Absorbance was measured at $645 \mathrm{~nm}$ and $663 \mathrm{~nm}$ in a spectrophotometer. The chlorophyll content was determined by using the following formula:

Chlorophyll a $(\mathrm{mg} / \mathrm{g}$.fr.wt $)=(12.7 \times \mathrm{A} 663-2.69 \times$ $\mathrm{A} 645) /(\mathrm{a} \times 1000 \times \mathrm{W}) \times \mathrm{V}$

Chlorophyll b $(\mathrm{mg} / \mathrm{g}$.fr. wt $)=(22.9 \times \mathrm{A} 645-4.68 \times$ $\mathrm{A} 663) /(\mathrm{a} \times 1000 \times \mathrm{W}) \times \mathrm{V}$

Total Chlorophyll $(\mathrm{mg} /$ g.fr.wt $)=(20.2 \times \mathrm{A} 645-8.02 \times$ $\mathrm{A} 663) /(\mathrm{a} \times 1000 \times \mathrm{W}) \times \mathrm{V}$

Where, $\mathrm{A}=$ Absorbance at respective wave length, $\mathrm{V}=$ Volume of extract $(\mathrm{ml})$, fr. wt $=$ Fresh weight of the sample (g)

The chlorophyll was expressed on a dry weight basis (mg.g-1 DW)

\subsection{Estimation of Carotenoid}

The amount of Carotenoid was estimated by the method of [16]. The same chlorophyll extract was measured at
$480 \mathrm{~nm}$ in spectrophotometer to estimate the carotenoid content.

Carotenoid: $\mu \mathrm{g} . \mathrm{g}-1$ fr wt $=\Delta \mathrm{A} 480+(0.114 \times \Delta \mathrm{A} .663)-$
$(0.638 \times \Delta \mathrm{A} 645)$

Where, $\Delta \mathrm{A}=$ Absorbance at respective wave length

\subsection{Estimation of Protein}

Protein content in seaweeds was determined by standard AOAC methods [14]. Protein content was calculated by converting the nitrogen content, determined by microKjeldahl method $(6.25 \times \mathrm{N})$.

\subsection{Estimation of lipid}

Lipid content was determined by taking a sample weighing $3 \mathrm{~g}$ in filter paper sacks and placing it into the Soxhlet system AOAC [14]. The extraction was continuously over 6 hours using petroleum ether as solvent.

\subsection{Amino acid analysis}

Amino acid content was determined by highperformance liquid chromatography (HPLC) according to the OJEC standard method [17]. A mass sample of alga powder samples was hydrolysed with $6 \mathrm{~N}$ hydrochloric acid in an ampule containing $0.1 \%$ phenol (for protection of tyrosine) for $24 \mathrm{~h}$ at $110^{\circ} \mathrm{C}$. After acid hydrolysis, $30 \mathrm{ml}$ of citrate buffer ( $\mathrm{pH} 2.2$ ) was added, and the $\mathrm{pH}$ was adjusted. The sample obtained was diluted to $100 \mathrm{~mL}$ with citrate buffer after adding $1 \mathrm{ml}$ of a norleucine solution 50 at $1 \mathrm{~mol}$ (as an internal standard). The sample was filtered through a $0.2 \mu \mathrm{m}$ nylon filter before being analysed by HPLC. Sulphurcontaining amino acids, cysteine and methionine were determined after a prehydrolysis oxidation with performic acids [17]. The contents of the different recovered amino acids were presented as g.100 $\mathrm{g}^{-1}$ protein (mg. $\mathrm{g}^{-1}$ protein).

\section{$2.9 \alpha$-Tocopherol analysis}

$\alpha$-Tocopherol was determined following the AOCS standard method [18].

\subsection{Estimation of total phenolic content (TPC)}

$0.5 \mathrm{~g}$ leaves were homogenized with $1 \mathrm{ml} 80 \%$ methanol at $4{ }^{\circ} \mathrm{C}$. The homogenate was centrifuged at $19,000 \mathrm{rpm}$ for $20 \mathrm{~min}$ and the supernatant was used for phenol content analysis. Phenolic content of the extract was estimated by the method of [19]. One hundred microliters of aliquot sample was mixed with $2 \mathrm{ml}$ of 2 $\% \mathrm{Na}_{2} \mathrm{CO}_{3}$ and allowed to stand for $2 \mathrm{~min}$ at room temperature.

After incubation, $100 \mu \mathrm{L}$ of $50 \%$ Folin-Ciocalteau's phenol reagent was added and then the reaction mixture was mixed thoroughly and allowed to stand for $30 \mathrm{~min}$ at 
room temperature in the dark. Absorbance of all the sample solutions was measured at $720 \mathrm{~nm}$ using a UVvisible spectrophotometer.

\subsection{Soil characterization}

Concerning the chemical characteristics of the soil, total $\mathrm{N}$ content was calculated following the [20]. Olsen method [21] was used to measure the available $\mathrm{P}$ in soil. Potassium content was measured by the method described by [22].

\subsection{Plant material and growth conditions}

Wheat plants were grown under controlled conditions under $16 \mathrm{~h}$ light regimes at $25^{\circ} \mathrm{C}$ and $8 \mathrm{~h}$ dark regime at $18^{\circ} \mathrm{C}$. Plants were grown in plastic pots containing soil. The different pots were watered every three days. The experiment was made in duplicates, it consists of four treatments: (control: water spray); 12.5, 25, and 50\% $(\mathrm{v} / \mathrm{v})$ of SWE in water. Sprays of seaweed liquid extract were applied, two times a week.

Plants were harvested 4 weeks after initiating seaweed treatments and the morphological characteristics such as shoot length and fresh weight were measured. All experiments and enzyme preparations were performed with freshly harvested plants.

\subsection{Preparation of plant extracts for enzyme activity assays}

Using a pre-cooled mortar and pestle, the leaves were homogenized in $50 \mathrm{mM}$ ice-cold phosphate buffer $(\mathrm{pH}$ 7.6) containing $14 \mathrm{mM} \quad \beta$-mercaptoethanol, $1 \mathrm{mM}$ Ethylenediaminetetraacetic acid (EDTA), $1 \mathrm{mM}$ phenylmethylsulfonyl fluoride (PMSF), 9.4 $\mu \mathrm{M}$ leupeptin and $10 \%(\mathrm{w} / \mathrm{v})$ glycerol. The homogenates were centrifuged at $12,000 \mathrm{rpm}$ for $20 \mathrm{~min}$ and the supernatants were used for determination of enzyme activities. All procedures were performed at $0-4{ }^{\circ} \mathrm{C}$.

For NADP-ICDH, the supernatant was saturated (60\%) with solid ammonium sulfate for $30 \mathrm{~min}$. The saturated supernatant was centrifuged again in the same conditions and the resulting pellet was resuspended in the extraction buffer and used for enzyme assays.

\subsection{Enzyme activity assays}

The activity of SOD (EC 1.15.1.1) was assayed according to the method described by [23].

The GR activity was determined by the oxidation of $\mathrm{NADPH}$ at $340 \mathrm{~nm}$ (extinction coefficient $6.2 \mathrm{mM}^{-1} \mathrm{~cm}^{-1}$ ) as described by [24]. The reaction mixture was composed of $100 \mathrm{mM}$ potassium phosphate buffer $(\mathrm{pH}$ 7.8), 2 mM EDTA, 0.2 mM NADPH, 0.5 mM GSSG and the appropriate volume of enzyme extract. The reaction was initiated by the addition of NADPH at $30^{\circ} \mathrm{C}$.

The activity of GST was determined by the method of [25] with some modification. Assay mixture contained enzyme extract, $5 \mathrm{mM}$ GSH, $2.5 \mathrm{mM}$ 1-chloro-2,4-dinitrobenzene (CDNB, and $0.1 \mathrm{M}$ phosphate buffer $(\mathrm{pH}$ 5.5). The reaction was monitored Spectrophotometrically at $340 \mathrm{~nm}$ at $30^{\circ} \mathrm{C}$. Concentrations of product were calculated using a molar extinction coefficient of $9.6 \mathrm{mM}^{-1} \mathrm{~cm}^{-1}$.

The NADP-ICDH activity was measured according to [26] with some modifications as reported by [27].

The assay mixture containing: $50 \mathrm{mM}$ potassium phosphate buffer (pH 7.5), $1 \mathrm{mM} \mathrm{MnCl}_{2}, 1 \mathrm{mM} \mathrm{NADP}+$, and $4 \mathrm{mM}$ isocitrate.

The total soluble protein content of the enzyme extracts was determined following the method of [28], using bovine serum albumin (BSA) as a protein standard.

\subsection{Statistical analysis}

Data were analyzed statistically for standard deviation using SPSS 13.0 (SPSS Inc., Chicago, IL, USA).

All measurements were performed with triplicates and the mean values were presented.

\section{Results and discussion}

\subsection{Algae analysis}

\subsubsection{Mineral elements and pigment composition}

The mineral elements in the Ulva rigida macroalgae are listed in Table 1.

Table 1. mineral composition of seaweed (mg.100 g-1 DW)

\begin{tabular}{cc}
\hline Minerals & Ulva rigida \\
\hline $\mathrm{K}$ & $1233.05 \pm 49.2^{\mathrm{b}}$ \\
$\mathrm{Mg}$ & $3510.17 \pm 68.1^{\mathrm{a}}$ \\
$\mathrm{Ca}$ & $680.55 \pm 31.6^{\mathrm{c}}$ \\
$\mathrm{Na}$ & $421.28 \pm 15.4^{\mathrm{d}}$ \\
$\mathrm{Cl}$ & $152.965 \pm 12.0^{\mathrm{e}}$ \\
\hline
\end{tabular}

Results are means \pm S.D $(n=3)$ Different letters show statistically significant differences for $\mathrm{P}<0.05$.

The means of macro elements: $\mathrm{K}, \mathrm{Cl}, \mathrm{Mg}, \mathrm{Na}$ and $\mathrm{Ca}$ contents was $1233.05 \mathrm{mg} .100 \mathrm{~g}^{-1} \mathrm{DW} ; 152.96 \mathrm{mg}^{100 \mathrm{~g}^{-1}}$ DW; 3510 mg. $100 \mathrm{~g}^{-1}$ DW; 421 mg. $100 \mathrm{~g}^{-1} \mathrm{DW}$ and $680.55 \mathrm{mg} 100 \mathrm{~g} \mathrm{~g}^{-1} \mathrm{DW}$ respectively. Thus, Ulva rigida is rich in $\mathrm{Mg}$ followed by $\mathrm{K}$ and $\mathrm{Ca}$ but low in $\mathrm{Na}$ and $\mathrm{Cl}$. The studies of [29] for Ulva Lactuca and Ulva Rigida from the mean coastal area of the Black Sea showed that $\mathrm{Mg}, \mathrm{Fe}$ and $\mathrm{Zn}$ are the major constituent of this green algae. [30] estimated various mineral content available in Stoechospernum marginatum and padina sp. The results showed that the total concentration of the minerals was always high in padina $\mathrm{sp}$ as compared to that in Stoechospernum marginatum [31]. This wide range of mineral content, not found in plants, is related to factors such as seaweed phylum, geographical origin and seasonal, environmental and physiological variations [32]. Mineral content also depends on the type of 
seaweed processing and on the mineralization methods used [33].

Concerning the pigment content (Figure 1), it was varied greatly due to the presence of chlorophyll a; chlorophyll b and total chlorophyll. Total chlorophyll was extremely low $\left(0.067 \mathrm{mg}\right.$. $\left.\mathrm{g}^{-1} \mathrm{DW}\right)$ in comparison with carotenoids $\left(0.929 \mathrm{mg}\right.$. $\left.\mathrm{g}^{-1} \mathrm{DW}\right)$. [34] reported that in Ulva rigida collected from marine coastal region of Chilka Lake, the pigment composition was varied greatly due to the presence of Chlorophyll a (13\%), chlorophyll b $(7.5 \%)$ and Carotenoids (4.5\%). The highest concentration of carotenoid found in our study was consistent with results obtained by [35] for Gymnogongrus Griffthsiae that contained higher concentrations of total carotenoids compared to total chlorophyll (50\% higher). These results point to the role of carotenoids as shields to protect the photosystems [36]. The same study showed that the presence of different quantities and kinds of pigment (chlorophyll, carotenoids, phycoerythrin) results in a high capacity to absorb light in virtually all visible light.

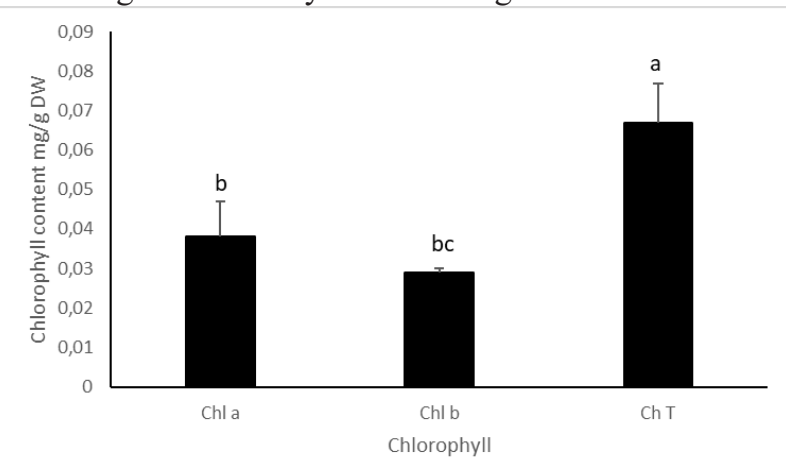

Fig. 1. Pigment composition chlorophyll a, chlorophyll b and chlorophyll total content in macroalgae specie Ulva rigida; $\mathrm{Chl}$ a: chlorophyll a, Chl b: chlorophyll b, Chl T: chlorophyll Total. Results are means \pm S.D. Different letters in a single line show statistically significant differences for $\mathrm{P}<0.05$ level.

\subsubsection{Protein and lipid content}

Total protein and lipid contents analyzed in the green algae are summarized in Figure 2. The protein content found in the green macroalgae was relatively higher than lipid content $\left(9.3\right.$ g. $100 \mathrm{~g}^{-1} \mathrm{DW}$ and 2.83 g. $100 \mathrm{~g}^{-1} \mathrm{DW}$, respectively). [37] reported that these levels varied depending on algal species, season and environment. Most of the studies on major chemical components of seaweeds have focused on the nutritional properties of the species, e.g. [38]. However, analyses of the major chemical components are important tools for environmental issues [39].

The low lipid content of Ulva rigida is in line with the results obtained in previous studies [40]. In the different articles in the literature, the lipid content in seaweeds is generally less than $4 \%$ [41]. The differences are probably related to factors such as the development stage of seaweeds, climate and geography.

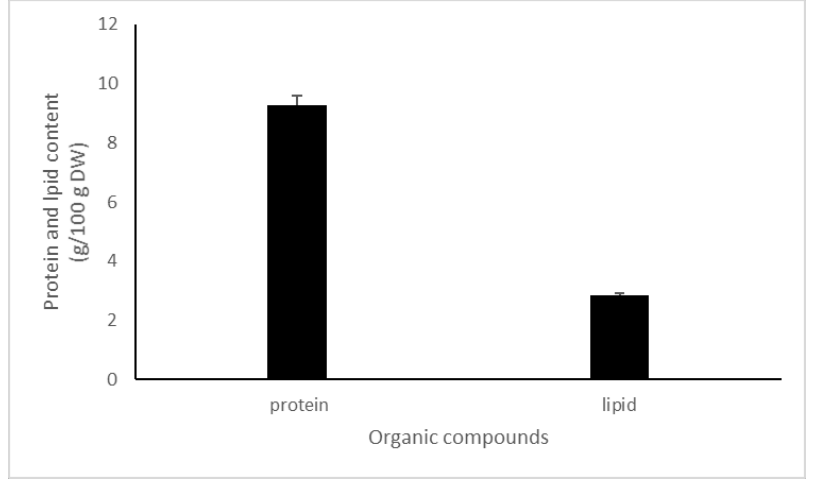

Fig. 2. Total protein and lipid content in Ulva rigida. Results are means \pm S.D. Different letters in a single line show statistically significant differences for $\mathrm{P}<0.05$ level.

\subsubsection{Amino acid composition}

The amino acid contents of Ulva rigida are illustrated in Figure 3. The essential amino acids (EAA) included methionine, leucine, isoleucine, lysine, phenylalanine, tyrosine, arginine, threonine, valine and tryptophan. The levels of the different essential amino acids ranged from 0.646 to 15.83 g. $100 \mathrm{~g}^{-1}$ protein. Ulva rigida contain a large amount of leucine (15.8 g. $100 \mathrm{~g}^{-1}$ protein) and less content of lysine and methionine $1,93 \mathrm{~g} .100 \mathrm{~g}^{-1}$ protein and 0,64 g. $100 \mathrm{~g}^{-1}$ protein, respectively. The Nonessential amino acids (NEAA), namely histidine, aspartic acid, glutamic acid, serine, proline, glycine, and alanine, ranged from 3.7 to $19.6 \mathrm{~g}$. $100 \mathrm{~g}^{-1}$ protein. This marine macroalgae contained a large amount of aspartic (19.6 g.100 $\mathrm{g}^{-1}$ protein) and glutamic acids (9.2 g.100 $\mathrm{g}^{-1}$ protein), followed by alanine (10.44 g. $100 \mathrm{~g}^{-1}$ protein), glycine $\left(9.19\right.$ g. $100 \mathrm{~g}^{-1}$ protein), serine $\left(3.98\right.$ g. $100 \mathrm{~g}^{-1}$ protein) and proline (6.67 g. $100 \mathrm{~g}^{-1}$ protein). The lower quantity for these Non- EAA was histidine $\left(3.7\right.$ g. $100 \mathrm{~g}^{-1}$ protein). Similar results have been obtained in previous studies [42].

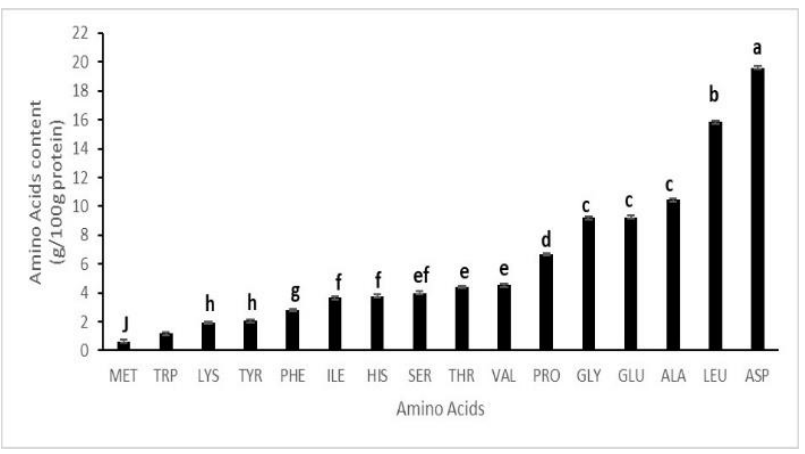

Fig. 3. Amino acid content of Ulva rigida from Akhfenir coastal. Results are means \pm S.D. Different letters in a single line show statistically significant differences for $\mathrm{P}<0.05$ level.

\subsubsection{Polyphenols and $\alpha$ tocopherol content}

The seaweed species showed significant differences between total phenolic and $\alpha$ tocopherol contents that are $0.99 \mathrm{mg}$. $\mathrm{g}^{-1} \mathrm{DW}$ and $7.31 \mu \mathrm{g}$. $\mathrm{g}^{-1} \mathrm{DW}$, respectively (Figure 4). Previous studies reported that the highest 
content of polyphenol was found in brown seaweeds, where phlorotannin range from 5 to $15 \%$ of the dried weight [43]. Moreover, brown algae generally contained higher amounts of polyphenols than red and green algae [44].

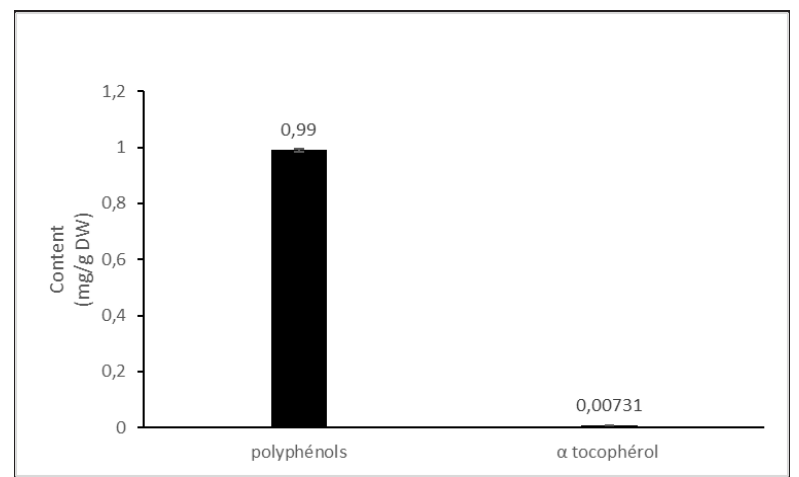

Fig. 4. Polyphenols and $\alpha$ tocopherol content in macroalgae species (Ulva rigida). Results are means \pm S.D. Different letters in a single line show statistically significant differences for $\mathrm{P}<0.05$ level.

Phenolic compounds are commonly found in plants and have been reported to have several biological activities including antioxidant properties [45]. Liquid extract obtained from seaweeds has recently gained much interest as a foliar spray for inducing growth and yield in cereal crops, vegetables, fruits, orchards and horticultural plants [46]. It has found wide application in modern agriculture for the use of marine macroalgae as fertilizer [7].

In this study, we have tried to investigate the importance of Moroccan seaweed extracts on the growth of wheat plants (Triticum durum L.) using different concentrations of Ulva rigida extract (URE).

\subsection{Plant analysis}

\subsubsection{Effect of URE on plant growth and oxidative stress metabolism of wheat plants}

The present study was conducted in controlled conditions, however, as substrate for the plant growth, we used a soil that has never received any fertilizer. Moreover, no fertilizers have been added during this experiment. The analysis of the soil was conducted and the results of the main macroelements $(\mathrm{N}, \mathrm{P}$ and $\mathrm{K})$ are presented in the table 2 .

Table 2. Selected chemical characteristics of the used soil.

\begin{tabular}{cccc}
\hline Chemical & $\mathrm{P}_{2} \mathrm{O}_{5}(\mathrm{ppm})$ & $\mathrm{K}_{2} \mathrm{O}(\mathrm{ppm})$ & $\mathrm{N}(\%)$ \\
\hline Concentration & $13.16 \pm 0,056$ & $147,575 \pm 0$, & $0.146 \pm 0.004$ \\
\hline $\begin{array}{c}\text { Soil } \\
\text { characteristics }\end{array}$ & $\begin{array}{c}\text { Moderately } \\
\text { poor }\end{array}$ & Poor $^{2}$ & Moderately poor $^{3}$ \\
\hline
\end{tabular}

1 , according to [21]; 2, according to [22];3, according to [20].
To evaluate how the Ulva rigida extract (URE) affects wheat plants, some growth parameters as length and fresh weights were determined (Table 3 ).

Table 3. Biomass accumulation of wheat shoots growing at increased levels of Ulva rigida extracts.

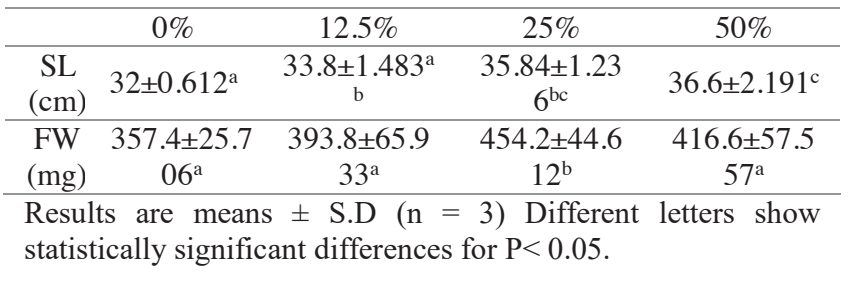

The table 3 shows the effect of URE on the growth parameters of wheat shoots. From these results, we can observe that URE contributes in a beneficial way to the growth of the wheat shoots. In fact, the length of the aerial part of the treated plants was significantly greater compared to the control plants. The highest values of shoot length were obtained for the plants treated with $25 \%$ and $50 \%$ of URE. For the fresh weight, the seaweed extract exerted a positive effect, however, the differences between the treated plants and the control were significative only in the concentration of $25 \%$. These results are in line with those obtained by [5] who worked on extracts obtained from Ulva lactuca. The same observations were obtained by [9] with the brown seaweed, Fucus spiralis, that led to a significant enhancement of the growth of Durum wheat plants.

Although in this experiment, the plants were grown on a N-, P- and K- deficient soil (Table 2), the utilization of the seaweed extract was able to increase the plant growth of the wheat plants, especially at $25 \%$ of the URE. This result could indicate a stimulatory effect of the seaweed extract on the absorption capacity of wheat plants under soil deficient conditions.

The effect of the seaweed extracts, Ulva rigida, was also evaluated in the antioxidant system through the determination of enzyme activities such as SOD, GST and GR. In fact, the present study was performed on a poor soil and our study was also conducted without adding any fertilizer. The low bioavailability of certain macro and microelements of this soil could therefore lead to a certain level of oxidative stress as it was previously stated in different works [46]. When plants are exposed to stress factors, an increase of the reactive oxygen species (ROS) is observed [47]. To maintain ROS under normal levels, plants can evolve a multitude of protective mechanisms, among of the them, the activation of the antioxidative enzymes such as, SOD, GST and GR [48].

Superoxide dismutase (SOD) is considered to be the first enzyme which behaves as a barrier against ROS [49], and which is responsible for the dismutation of the superoxide anion radicals (O2-) to hydrogen peroxide $\left(\mathrm{H}_{2} \mathrm{O}_{2}\right)$. In the present study, we did not observe any significant differences between the control plants and those treated with $12.5 \%$ of the seaweed extract, However, we surprisingly noticed a decrease in the SOD activity after treatment with $25 \%$ and $50 \%$ of the 
seaweed extract (Figure 5). As SOD is activated under conditions of stress and as the present study was conducted on soil without the addition of any fertilizers, the culture conditions led probably to an oxidative stress of wheat plants which, in return, led to the activation of the SOD enzyme. Moreover, the seaweed extracts at the concentrations of $25 \%$ and $50 \%$, which were able to induce an increase in plant growth, were probably responsible for alleviating the stressful factors and explain therefore the decrease in the SOD activity at these concentrations. The obtained result is in line with the works conducted on the effect of seaweed extracts as biostimulants and their ability to improve nutrient uptake [50].

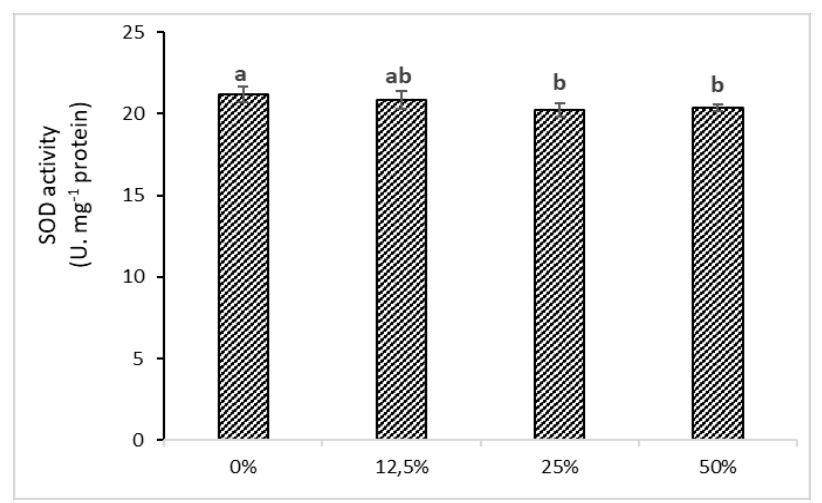

Fig. 5. Effect of seaweed extract on leaves superoxide dismutase (SOD) activity of wheat plant. Results are means \pm S.D. Different letters show statistically significant differences for $\mathrm{P}<0.05$ level.

Our data reveal that in leaves of wheat, the GR activity was enhanced at the concentration of $25 \%$ of URE and reach $24.3 \mathrm{nmol}$. $\mathrm{min}^{-1}$. $\mathrm{mg}^{-1}$ protein compared to the control with $22.5 \mathrm{nmol}$. $\mathrm{min}^{-1}$. $\mathrm{mg}^{-1}$ protein (Figure $6)$. The high activity of GR enzyme, responsible for reducing oxidized glutathione (GSSG) to its reduced form (GSH), could be a response to the high demand for $\mathrm{GSH}$, needed both for detoxifying plant cells from $\mathrm{H} 2 \mathrm{O} 2$ and also for its role in different metabolisms required for plant growth and development [47]. In fact, GR is implicated in maintaining high content of the reduced glutathione in plant cells. The GSH is used in several redox reactions, among of them, those responsible for the amino acid transport and protein and DNA synthesis [51]. High ratio of GSH/GSSG was also reported to be required for accelerating the $\mathrm{H}_{2} \mathrm{O}_{2}$ scavenging pathway, especially when plants are facing stressful conditions $[48,52]$. The increase in plant height and fresh weight at the concentration of $25 \%$ of seaweed could explain the high level of the GR enzyme at this condition, to allow synthesis of high levels of GSH required for the metabolic pathways implicated in biomass production and also to cope with the eventual stressful conditions that face wheat plants.

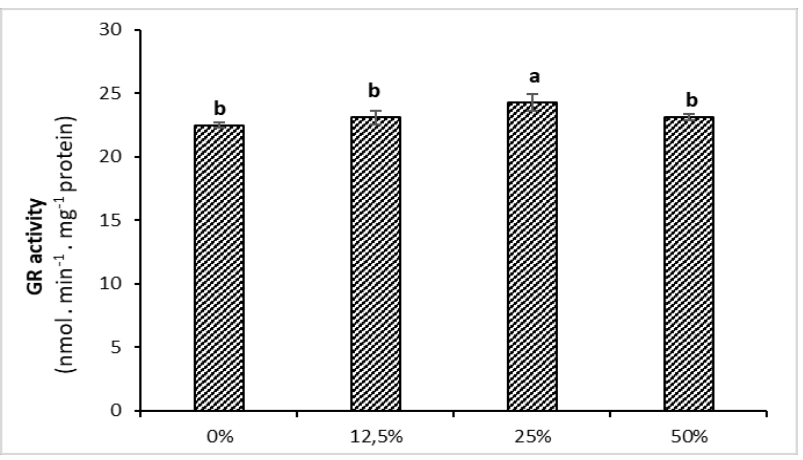

Fig. 6. Effect of seaweed extract on leaves glutathione reductase (GR) activity of wheat plant. Results are means \pm S.D. Different letters show statistically significant differences for $\mathrm{P}<0.05$ level.

Our results indicated that GST activity increased only at the concentration of $50 \%$ of URE (Figure 7). It is known that GST may help reduce a wide range of organic hydroperoxides in the presence of GSH [48]. It has been shown that GST enzyme can protect plants exposed to salt stress and to encounter its effect against lipid peroxidation [53]. In another study, [54] reported that GST is implicated in the detoxification pathway to reduce the impact of high levels of cadmium in Phragmites australis. In our results, GST was affected by the concentration of $50 \%$ of URE only. As the high concentration of seaweed extracts could have a negative effect on plant growth and could trigger oxidative stress in the treated plants, the $50 \%$ concentration used in this study may be considered as too high to be used as biostimulant and should therefore be avoided for wheat plants. As this work has been conducted at only 4 weeks, another study for the whole cycle of wheat should be conducted to validate this hypothesis.

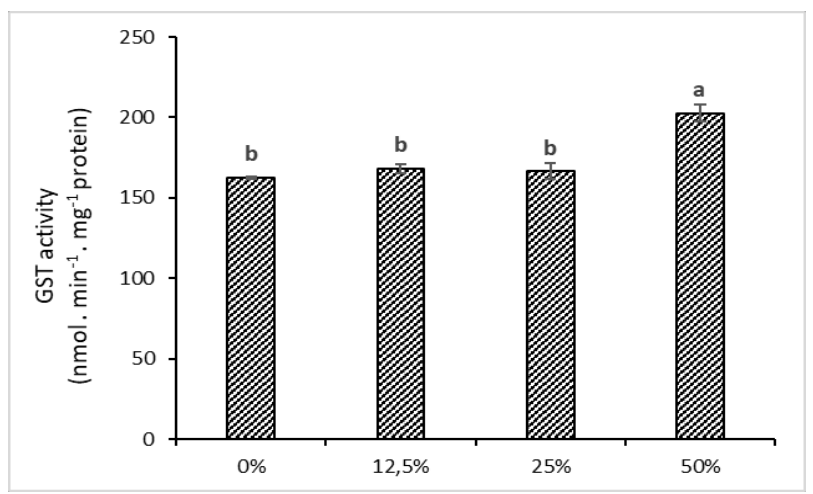

Fig. 7. Effect of seaweed extract on leaves glutathione Stransferase (GST) activity of wheat plant. Results are means \pm S.D. Different letters show statistically significant differences for $\mathrm{P}<0.05$ level.

It is known that the glutathione-dependent system requires $\mathrm{NADPH}$, as cofactor, to face reactive oxygen species resulted from the oxidative stress [27]. Therefore, low content of NADPH can disturb the cell response to these toxic compounds. NADP ${ }^{+}-\mathrm{ICDH}$ is a key enzyme, responsible for the synthesis of NADPH [55]. In fact, the study conducted by [56] revealed that the high activity of $\mathrm{NADP}^{+}-\mathrm{ICDH}$ was observed in 
leaves of Mesembryanthemum crystallinum grown under salinity stress conditions. In addition, it is proposed that $\mathrm{NADP}^{+}$-ICDH dehydrogenase acts in Arabidopsis seedlings as a second barrier in the response mechanism of abiotic stress especially salt stress [57].

In the present work, the activity of $\mathrm{NADP}^{+}-\mathrm{ICDH}$ has been increased in all conditions of plant treatment with the seaweed extracts and the increase was dosedependent (figure 8). The increase in the NADP+-ICDH activity could be responsible for the provision of NADPH, used to counteract oxidative stresses that could be generated in the culture conditions of our experiments. The increase in the NADP+-ICDH could also be due to a higher demand for carbon skeletons in the forms of 2-oxoglutarate as proposed by [58]. The carbon generated through this reaction may be used for the process of biosynthesis of amino acids [59].

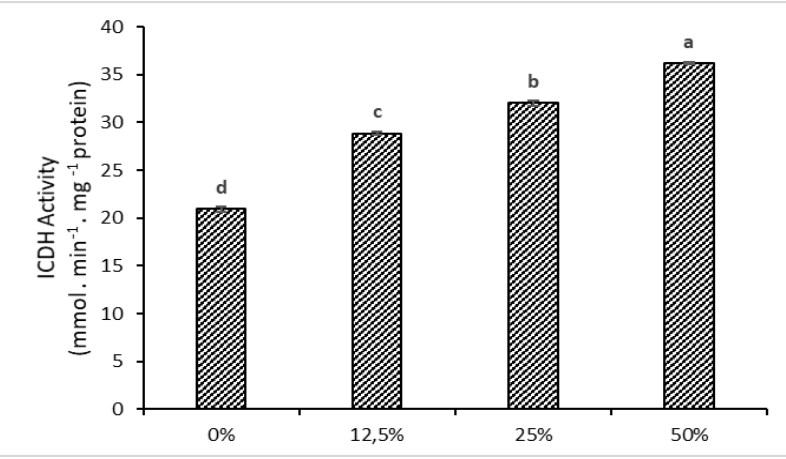

Fig. 8. Effect of seaweed extract on leaves isocitrate dehydrogenase (ICDH) activity of wheat plant. Results are means \pm S.D. Different letters show statistically significant differences for $\mathrm{P}<0.05$ level.

\section{Conclusion}

The seaweed species Ulva rigida examined in this study were rich in $\mathrm{Mg}$ followed by $\mathrm{K}$ and $\mathrm{Ca}$ but low in $\mathrm{Na}$ and $\mathrm{Cl}$, have high carotenoid contents, appreciable protein contents, low total lipid contents, high content of antioxidant (total phenolic and $\alpha$ tocopherol) and the large amount of phenylalanine, leucine, aspartic acid and glutamic acid.

In the present study, we observed that $25 \%$ and $50 \%$ of $U$. rigida liquid extracts applied at wheat plants showed higher shoot length. This extract also enhanced the antioxidant potential of plants by activation of the antioxidant enzymatic system of SOD, GR, and GST which can contribute to plant protection against oxidative stress imposed by environmental stress. The same correlation was found between resistance to oxidative stress and antioxidant properties. Alternatively, in some plants, increased resistance to abiotic stresses has been achieved by exogenous application of various organic solutes.

Consequently, the present findings encourage the application of Moroccan green seaweed (Ulva rigida) as natural fertilizer in the agricultural sector. However, it would be beneficial to carry out more research, including studies of antioxidant and substances active in seaweeds extract that stimulate the enzymatic system and lead to oxidative stress tolerance in wheats plants and highlight in the mechanism(s) of actions of seaweed extract elicited physiological responses.

\section{References}

1. M.C. Hunter, R.G. Smith, M.E. Schipanski, L.W. Atwood, D.A. Mortensen, BioScience 67(4), 386-391 (2017) DOI : 10.1093/biosci/bix010

2. J.G. de salvia, G.F. Houngbo, H.H. Fore, D. Beasley, T.A. Ghebreyesus, The state of food security and nutrition in the world 2018: Building climate resilience for food security and nutrition. Food \& Agriculture Org (2018)

3. N. Abdel-Raouf, African Journal of Biotechnology 11,54 (2012) DOI : $10.5897 / A J B 11.3983$

4. B. Pramanick, K. Brahmachari, A. Ghosh, S.T. Zodape, Bangladesh Journal of Botany 43(1), 53-58 (2014)

5. R. Kavipriya, P.K. Dhanalakshmi, S. Jayashree, N. Thangaraju, Journal of Ecobiotechnology 4, (2011)

6. E. Nabti, B. Jha, A. Hartmann, International Journal of Environmental Science and Technology 14(5), 1119-1134. (2017)

7. S. Latique, H. Chernane, M. Mansori, M. El Kaoua, European Scientific Journal 9(30), (2013)

8. S. Latique, M.A. Elouaer, H. Chernane, C. Hannachi, M. El kaoua, International Journal of Innovation and Applied Studies 7(4), 1430 (2014)

9. S. Latique, M.A. Elouaer, H. Chernane, C. Hannachi, M. El kaoua, Communications in Soil Science and Plant Analysis 48(21), 2582-2593 (2017)

10. R.D. Lopes, R. Rordorf, G.M. De Ferrari, S. Leonardi, L. Thomas, D.M. Wojdyla, P. Ridefelt, J.H. Lawrence, R. De Caterina, D. Vinereanu, Journal of the American College of Cardiology 71(10), 1063-1074. (2018)

11. N. Berik, E.C. Çankırılıgil, Aquat Sci Eng 34(3), 74-79. (2019)

12. L.C. Irkin, Institute of Applied Sciences (2009)

13. S. Sivasankari, V. Venkatesalu, M., Anantharaj, M. Chandrasekaran, Bioresource technology 97(14), 1745-1751 (2006)

14. P. Cunniff, D.C. Washington, Journal of AOAC International 80(6), 127A (1997)

15. D.I. Arnon, Plant Physiology 24(1), 1-15 (1949) DOI : 10.1104/pp.24.1.1

16. J.T.O Kirk, R.L. Allen, Biochemical Society Transactions 603, 591. (1965)

17. OJEC, O. Official Journal of the European Communities (1998)

18. Ce, A. Ce 8-89 AOCS official Method (1993)

19. M.S. Taga, E.E. Miller, D.E. Pratt, Journal of the American Oil Chemists' Society 61(5), 928-931 (1984) 
20. C. Kjeldahl, Z Anal Chem, 22, 366 (1883)

21. S.R. Olsen, Estimation of available phosphorus in soils by extraction with sodium bicarbonate 939 US Department of Agriculture (1954)

22. N.S. Mountier, J.L. Griggs, G.A.C. Oomen, New Zealand journal of agricultural research 9(2), 328-338 (1966)

23. C. Beauchamp, I. Fridovich, Analytical Biochemistry 44(1), 276-287 (1971) DOI :10.1016/0003-2697(71)90370-8

24. M.V. Rao, G. Paliyath, D.P. Ormrod, Plant physiology 110(1), 125-136 (1996)

25. W.H. Habig, M.J. Pabst, W.B. Jakoby, Journal of biological Chemistry 249(22), 7130-7139 (1974)

26. J.R. Magalhaes, D.M. Huber, Journal of Plant Nutrition 14(2), 175-185 (1991)

27. R. Ben Mrid, N. Bouchmaa, Y. Bouargalne, B. Ramdan, K. Karrouchi, I. Kabach, M. El Karbane, A. Idir, A. Zyad, M. Nhiri, Molecules 24(3), 502 (2019) DOI : 10.3390/molecules24030502

28. M.M. Bradford, A Rapid and Sensitive Method for the Quantitation of Microgram Quantities of Protein Utilizing the Principle of Protein-Dye Binding. 7. (s. d.)

29. S. Rodica, S. Constanta, G.D. Lucia, N. Passy, Scientific Study and Research, 7(1), 193-198 (2006).

30. R. Dhamotharan, An investigation on the bioactive principles of Padina tetrastromatica Hauck and Stoechospermum marginatum (C. AG) Kuetz. With respect to antimicrobial and biofertilizer properties. $\mathrm{Ph}$. D Thesis, University of Madras, Chennai, Tamilnadu. (2002)

31. R. Dhamotharan, H. Sridevi, S. Murugesan, P. Murugakootan, Int J Appl Sci Nanotechnol 1, 21-28 (2012)

32. S. Mabeau, J. Fleurence, Trends in Food Science \& Technology 4(4), 103-107 (1993)

33. J. Santoso, Y. Yoshie, T. Suzuki, Jurnal Ilmu-Ilmu Perairan dan Perikanan Indonesia 11(1), 45-51 (2004)

34. G.G. Satpati, R. Pal, J. Algal Biomass Utln 2(4), 10-13 (2011)

35. A. Nascimento, C. Coelho-Gomes, E. Barbarino, S.O. Lourenço, Open Journal of Marine Science 2014

36. K.S. Rowan, Cambridge University Press 1, 112-166 (1989)

37. H. Yaich, H. Garna, S. Besbes, M. Paquot, C. Blecker, H. Attia, Food chemistry 128(4), 895-901 (2011)

38. M. Munier, J. Dumay, M. Morançais, P. Jaouen, J. Fleurence, Journal of Chemistry (2013)

39. L.J. Yu, S. Wang, X.M. Jiang, N. Wang, C.Q. Zhang, Journal of Thermal Analysis and Calorimetry 93(2), 611-617 (2008)
40. A. Polat, S. Polat, A. Simsek, T.T. Kurt, G. Ozyurt, Environmental Science and Pollution Research 25(4), 3756-3764 (2018)

41. P. Prabhasankar, P. Ganesan, N. Bhaskar, Food science and technology international 15(5), 471-479. (2009)

42. V. Gressler, N.S. Yokoya, M.T. Fujii, P. Colepicolo, J.M. Filho, R.P. Torres, E. Pinto, Food Chemistry, 120(2), 585-590 DOI:10.1016/j.foodchem.2009.10.028

43. A.G. McInnes, M.A. Ragan, D.G. Smith, J.A. Walter, Eleventh International Seaweed Symposium, 597-602 (1984)

44. M.A. Ragan, J.S. Craigie, Canadian journal of biochemistry 54 (1), 66-73. (1976)

45. T. Wang, R. Jonsdottir, G. Olafsdottir, Food chemistry 116(1), 240-248 (2009)

46. L. Andreu, N. Nuncio-Jáuregui, A.A. CarbonellBarrachina, P. Legua, F. Hernández, Journal of the Science of Food and Agriculture 98(4), 1566-1573 (2018)

47. V.C. Metha, B.S. Trivedi, K.K. Bokil, M.R. Narayana, Proc. Semi. Sea Salt 357-365 (1967)

48. R.B. Mrid, R.E. Omari, N.E. Mourabit, Y. Bouargalne, M. Nhiri, Australian Journal of Crop $\begin{array}{llll}\text { Science 12(08), } 1280-1287 & \text { (2018) DOI : }\end{array}$ 10.21475/ajcs.18.12.08.PNE1008

49. H. Chernane, S. Latique, M. Mansori, M. El Kaoua, IOSRJ Agric. Vet. Sci 8, 36-44. (2015).

50. R. El Omari, R. Ben Mrid, F. Chibi, M. Nhiri, Russian Journal of Plant Physiology 63(6), 719-726 (2016) DOI : 10.1134/S102144371606008X

51. R.G. Alscher, N. Erturk, L.S. Heath, Plants. 11 (s.d.)

52. S.S. Rathore, D.R. Chaudhary, G.N. Boricha, A. Ghosh, B.P. Bhatt, S.T. Zodape, J.S. Patolia, South African Journal of Botany 75(2), 351-355 (2009)

53. P. Frendo, M.A. Matamoros, G. Alloing, M. Becana, Frontiers in Plant Science 4, (2013) DOI : 10.3389/fpls.2013.00376

54. J. Pang, A. Wang, M. Zheng, T. Zhang, Chemical Communications 46(37), 6935-6937 (2010)

55. D. Sud, W. Zhong, D.G. Beer, M.A. Mycek, Optics Express 14(10), 4412-4426. (2006)

56. O.V. Popova, S.F. Ismailov, T.N. Popova, K.J. Dietz, D. Golldack, Planta 215(6), 906-913. (2002)

57. M. Leterrier, M. Chaki, M. Airaki, R. Valderrama, J. M. Palma, J. B. Barroso, F.J. Corpas, Plant Signaling and Behavior 6(6), 789-793 (2011)

58. R.D. Chen, P. Gadal, Plant Physiology and Biochemistry 28(1), 141-145 (1990)

59. R. Ben Mrid, R. El Omari, Y. Bouargalne, N. El Mourabit, M. Nhiri, Cereal Research Communications 45(4), 587-597 (2017) DOI : 10.1556/0806.45.2017.044 